\title{
Teaching Mode of Library Information Literacy Course Based on Hierarchical Embedded Service
}

\author{
https://doi.org/10.3991/ijet.v15i10.13995 \\ Lu Pang \\ Shandong Women's University, Jinan, China \\ pangxiaolu123456@163.com
}

\begin{abstract}
With the development of computer technology and network processing technology, information literacy competency has become an essential ability for contemporary college students. The traditional teaching mode of information literacy takes the form of library literature retrieval. The teaching content is relatively boring and dull, and the teaching form is backward, which makes many students lack interest in learning and produces an adverse effect on students' improvement of information literacy required by their professional study. For this reason, in this paper, "hierarchical embedded service mode" was applied in the learning of information literacy course and an embedded information literacy teaching network composed of three elements, that is, teachers, learners and librarians, was built. After that, targeted information literacy teaching methods were designed from the perspectives of program, object, teaching content, teaching methods and teaching staff. On this basis, a teaching feedback mechanism for information literacy course with entrepreneurship and innovation as the goals was set up, which included 5 primary categories, course content, teaching design, interface design, media technology, and course management, and 25 secondary categories. It was found in a teaching experiment that the students have been greatly improved in terms of autonomous learning ability, learning interest, classroom activity and reading ability.
\end{abstract}

Keywords-Hierarchical embedding service mode; information literacy; entrepreneurship; innovation

\section{Introduction}

With the constant development of information age, our life has been significantly improved. People can acquire and create information legally in a convenient and rapid way, and information has become an indispensable resource in our life [1]. In terms of education, the implementation of embedded information is centered on students' education, carried out through the media of library, and needs to be jointly undertaken by teachers, learners and librarians. Hierarchical embedded service mode becomes an important teaching mode in modern times, and the teaching of library information literacy has been widely recognized and concerned about. According to the individualized information demands of learners, teachers and librarians develop a 
course plan jointly, work together to launch teaching practice, and integrate information literacy education in the teaching system of professional courses, so that learners can upgrade their information skills, as they grasp professional knowledge [2]. It is of irreplaceable significance and value for the broadening of teachers' train of thought, the promotion of learners' autonomic learning ability and the full use of resource information. However, hierarchical embedded service mode also encounters some difficulties when being practically used in the teaching of library information literacy course, for such problems as the education mode is unscientific, the teachers' education is somewhat stochastic, and students' learning is subject to their subjective consciousness, not systematic and scientific enough, and the role of library staff is not given full play to, etc. [3] All of these problems have, to some extent, restricted the effect and development of this teaching mode.

In this paper, this issue was investigated and the following innovations were made: first of all, hierarchical embedded service mode was used to study educational work. Currently, the embedded education mode has been widely applied in China, but there is very little hierarchical and staged education. So this is also one of the innovation points of this paper; secondly, under the background of cultivating "innovative and entrepreneurial" talents, this paper focused on innovation and entrepreneurship and laid an essential foundation for the cultivation of practical talents; thirdly, the author established an evaluation for the training effect of the information literacy course, to provide a framework basis for subsequent research.

\section{State of the Art}

In February 2015, the Association of College \& Research Libraries (ACRL) published Framework for Information Literacy for Higher Education, pointing out that information literacy "is the set of integrated abilities encompassing the reflective discovery of information, the understanding of how information is produced and valued, and the use of information in creating new knowledge and participating ethically in communities of learning" [4]. According to the definition of ACRL, embedded information literacy education was a new approach to embed information literacy education contents, such as information retrieval skills, information knowledge and information ethics, into the teaching process of liberal and professional courses, so as to cultivate integrated information literacy competency in an all-round way, such as the abilities to analyze, utilize and evaluate information. American colleges and universities are in the forefront of the world on the research of embedded information literacy education, whose main view is that information literacy competency "is not extraneous to the curriculum but is woven into the curriculum's content, structure, and sequence". For this reason, ACRL formulated Information Literacy Competency Standards for Higher Education [5] and blended information literacy standards into the professional courses. Teachers and libraries jointly designed and developed courses and achieved good teaching effects. Woodward et al. [6] designed a teaching case at the University of Wisconsinde to apply embedded teaching method in library information course, built a student- 
centered model of competency-based education (CBE) and achieved a satisfactory learning effect. Prof. Lamb [7] designed a set of individual-based library information literacy teaching modes, which was principally an online course with 46 chapters designed for students' problem-solving ability. The experiment proved that such kind of individual-based teaching can help students improve their information literacy.

The research on this issue in China started late. Compared with the United States, China regards information education mode in colleges and universities as independent of disciplines or learning. Although some universities insisted that information literacy course should be taken as one of the disciplines of colleges and universities, the promoting effect is not satisfactory and the teaching effect remains to be improved. Generally speaking, at present, the teaching modes of information literacy in China are divided into four types: one-off interventional [8], expansible [9], hierarchical [10] and whole-process tracking machine [11]. Inn this paper, the application of hierarchical embedded service information education in the teaching of library information literacy was investigated.

\section{The Application of Hierarchical Embedded Service Mode}

\subsection{The embedding Scheme of embedded service mode in the teaching of information literacy course}

The main participants of the embedded information literacy teaching network were teachers, learners and librarians and the specific learning process was that according to students' learning needs, as well as relevant rules and regulations of schools and libraries, teachers converted information and resources in the library into modern teaching resources and passed them on to students through scientific teaching strategies, so that students can achieve growth and benefit. The specific process and relationships among all kinds of factors and participants are as fig.1:

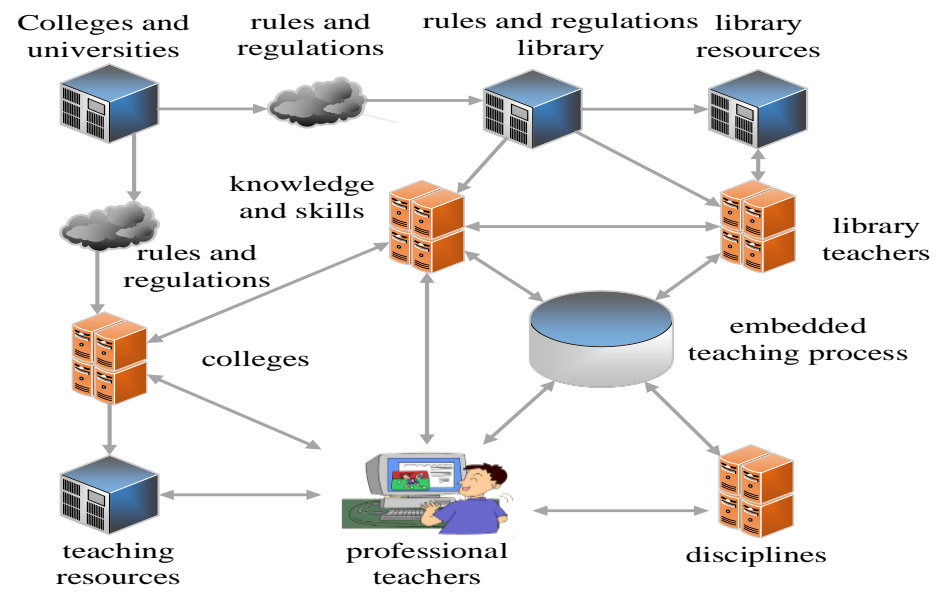

Fig. 1. The Teaching Process of Embedded Service Mode in Information Literacy Course 


\subsection{The teaching methods of hierarchical embedded service mode in information literacy course}

Table 1. The Teaching Methods of Hierarchical Embedded Service Mode in Information Literacy Course

\begin{tabular}{|c|c|c|c|}
\hline Program & $\begin{array}{c}\text { Primary Training } \\
\text { Stage } \\
\end{array}$ & Intermediate Education Stage & Advanced Training Stage \\
\hline Object & Freshmen & Sophomores and juniors & Seniors, masters and doctors \\
\hline $\begin{array}{l}\text { Teaching } \\
\text { Content }\end{array}$ & $\begin{array}{l}\text { Layout, collection and } \\
\text { services of libraries; } \\
\text { concept of information } \\
\text { literacy, etc. }\end{array}$ & $\begin{array}{l}\text { Computer-based retrieval methods, } \\
\text { online bibliographic retrieval of } \\
\text { libraries, introduction to common } \\
\text { databases and retrieval tools, } \\
\text { information literacy ethics and } \\
\text { morality, etc. }\end{array}$ & $\begin{array}{l}\text { Information retrieval of all } \\
\text { kinds of disciplines, the } \\
\text { retrieval and use of professional } \\
\text { databases, the writing of theses } \\
\text { and dissertations, etc. }\end{array}$ \\
\hline $\begin{array}{l}\text { Teaching } \\
\text { Methods }\end{array}$ & $\begin{array}{l}\text { Classroom } \\
\text { instructions, lectures } \\
\text { and library visits } \\
\end{array}$ & Instructions, practice and lectures & $\begin{array}{l}\text { Instructions, practice, lectures } \\
\text { and seminars }\end{array}$ \\
\hline $\begin{array}{l}\text { Teaching } \\
\text { Staff }\end{array}$ & Librarians & $\begin{array}{l}\text { Librarians and professional course } \\
\text { teachers }\end{array}$ & $\begin{array}{l}\text { Professional course teachers and } \\
\text { supervisors }\end{array}$ \\
\hline
\end{tabular}

It can easily be seen from Table 1 that the hierarchical embedded service modes in information literacy course were mainly categorized into primary training stage, intermediate education stage and advanced training stage. The main objects were freshmen, sophomores and juniors, seniors, masters and doctors respectively. The teaching activities were launched according to the characteristics and the learning needs of students at different stages. Among them, the primary stage mainly trained students' cognitive ability, the intermediate stage deepened students' cognition, while the advanced stage cultivated students' scientific research ability. 
3.3 The teaching mode of hierarchical embedded service mode under the background of mass entrepreneurship and innovation

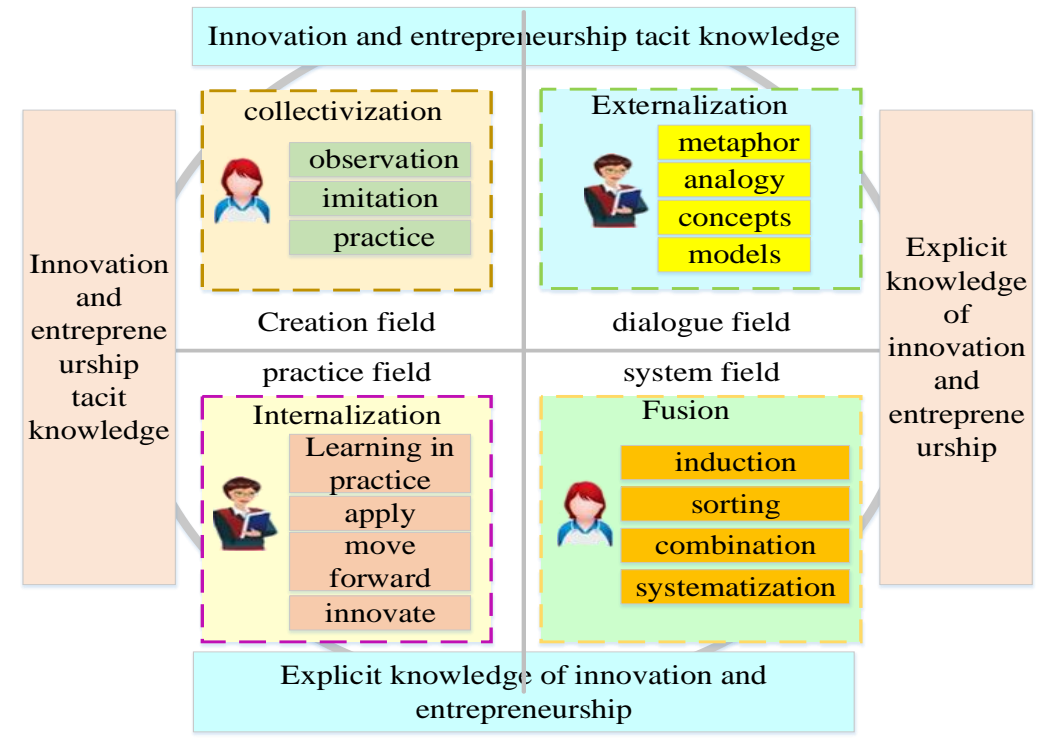

Fig. 2. The Teaching Mode of Hierarchical Embedded Service Mode under the Background of Mass Entrepreneurship and Innovation

Mass entrepreneurship and innovation mainly refers to innovation and entrepreneurship. Specifically speaking, it means that professionals who are engaged in services and brands communicate with each other freely, and students are given opportunities to contact professional scholars and talents, their innovative spirit was cultivated and their cognitive ability was improved [12]. Nowadays, with the rapid development of informatization, students are allowed to acquire information knowledge through a large number of network platforms and online libraries. It promotes the self-actualization of students, strengthens their information awareness and cultivates information creation talents who are adapted to the needs of social development.

The philosopher Micheal Polanyi contended that knowledge can be classified into explicit knowledge and tacit knowledge. According to this classification, the knowledge of entrepreneurs can be divided into the following two categories: the first category was entrepreneurial explicit knowledge, that is, the knowledge that entrepreneurs can clearly expressed through written words, symbols, images and databases, etc.

1. The popularization of tacit knowledge on innovation and entrepreneurship.It was manifested as "tacit knowledge- tacit knowledge" (see Fig. 2), that is, students needed to directly learn unique tacit knowledge on innovation and entrepreneurship through observation, imitation and practice. They perceived the know-hows of 
innovation and entrepreneurship through management games. Taking lessons given by experienced teachers, or attending relevant lectures and symposia in order to understand entrepreneurs' entrepreneurial experience in breaking routines, etc. can create a "field" which allows students to comprehend tacit knowledge on innovation and entrepreneurship.

2. The externalization of tacit knowledge on innovation and entrepreneurship. It was manifested as "tacit knowledge- explicit knowledge" (see Fig. 2). It meant that teachers clearly expressed tacit knowledge on innovation and entrepreneurship as a series of understandable words or visualized language and images (graphs) and other explicit knowledge in explicit ways, such as metaphor, analogy, concept and model.

3. The fusion of explicit knowledge on innovation and entrepreneurship. It was manifested as "explicit knowledge- implicit knowledge" (see Fig. 2), that is, students systematized all kinds of explicit knowledge on innovation and entrepreneurship that they had learned through summarization, sorting, combination and systematization, etc. and formed a knowledge system of innovation and entrepreneurship.

4. The internalization of explicit knowledge on innovation and entrepreneurship. It was manifested as "explicit knowledge- tacit knowledge" (see Fig. 2). In this stage, students were in a real entrepreneurial "field", and they needed to rely on their own efforts and persistence to sublime the explicit knowledge on entrepreneurship acquired above as entrepreneurs' easy-to-operate tacit knowledge, through learning by doing, application, transfer and innovation, etc. and let such tacit knowledge enter a new knowledge cycle.

\subsection{The evaluation model for the application of hierarchical embedded service mode in library information literacy course}

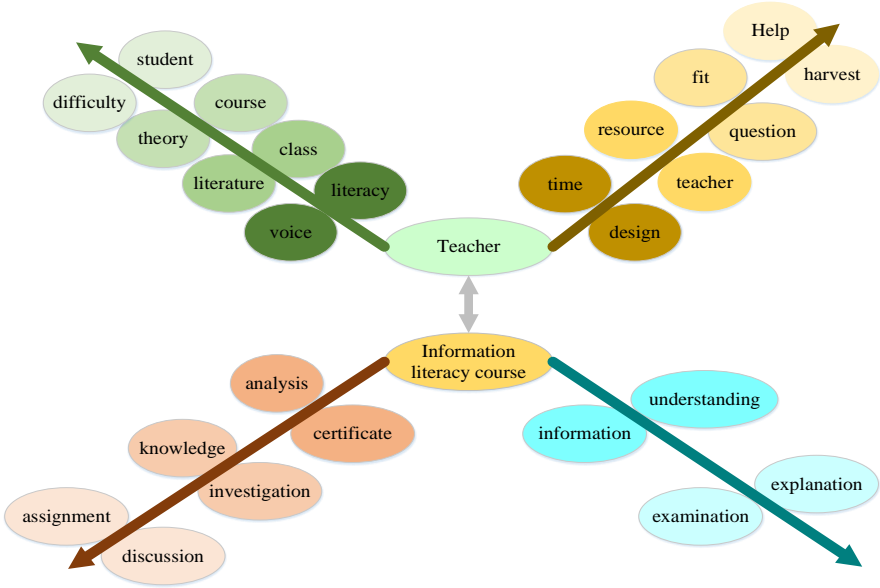

Fig. 3. Semantic Network Diagram 
It can easily be seen from Fig. 2 that in the library information literacy course, hierarchical embedded service mode focused on teachers and course, learners can acquire information and evaluation through a variety of channels and ways, evaluate and analyze themselves, and effectively improve their autonomous learning ability, as well as their innovative and entrepreneurial abilities, and promote their level of informatization.

Table 2. Comprehensive Evaluation Indicator System

\begin{tabular}{|c|c|c|c|}
\hline $\begin{array}{l}\text { Primary } \\
\text { Categories } \\
\text { (Weight) }\end{array}$ & $\begin{array}{l}\text { Secondary } \\
\text { Categories }\end{array}$ & Weight & Detailed Description \\
\hline \multirow{6}{*}{$\begin{array}{l}\text { Course Content } \\
0.323\end{array}$} & Course introduction & 0.05 & $\begin{array}{l}\text { To introduce the scope, objective, types and characteristics } \\
\text { of learners, prerequisite course, learning time and learning } \\
\text { tips, etc. }\end{array}$ \\
\hline & $\begin{array}{l}\text { Consistency } \\
\text { between content and } \\
\text { objective }\end{array}$ & 0.211 & $\begin{array}{l}\text { The content and learning objective of this course should be } \\
\text { consistent. It was required that the content should cover all } \\
\text { learning objectives of this course, and the depth should be } \\
\text { adapted to the learning objectives. }\end{array}$ \\
\hline & Scientificity & 0.254 & $\begin{array}{l}\text { The course content was scientific and rigorous, and there } \\
\text { were no ideological, academic and expressive errors, the } \\
\text { sources of teaching materials were reliable; the teaching } \\
\text { content can reflect the latest development in the field of } \\
\text { this teaching philosophy }\end{array}$ \\
\hline & Knowledge quantity & 0.192 & $\begin{array}{l}\text { The course content included the total } \\
\text { quantity of knowledge that can eliminate students' } \\
\text { uncertainties }\end{array}$ \\
\hline & $\begin{array}{l}\text { Content } \\
\text { Arrangement }\end{array}$ & 0.192 & $\begin{array}{l}\text { The course content was organized and arranged in a } \\
\text { reasonable way based on the psychological characteristics } \\
\text { and behavioural habits of learners, according to the logical } \\
\text { relationship between modules }\end{array}$ \\
\hline & Resource expansion & 0.101 & $\begin{array}{l}\text { Valuable external resource links related to the course } \\
\text { content were provided. }\end{array}$ \\
\hline \multirow{8}{*}{$\begin{array}{l}\text { Teaching } \\
\text { Design }(0.358)\end{array}$} & Learning objective & 0.247 & $\begin{array}{l}\text { Each learning unit had accurate and specific learning } \\
\text { objective. }\end{array}$ \\
\hline & $\begin{array}{l}\text { Motivation and } \\
\text { interest }\end{array}$ & 0.154 & $\begin{array}{l}\text { Appropriate strategies closely aligned with the course } \\
\text { content were adopted to attract the learners' attention, } \\
\text { inspire and maintain their learning motivation and interest. }\end{array}$ \\
\hline & $\begin{array}{l}\text { Teaching method } \\
\text { and mode }\end{array}$ & 0.116 & $\begin{array}{l}\text { Teachers adopted proper teaching methods that were } \\
\text { beneficial to the analysis and explanation of course content, } \\
\text { based on the course content and acceptance type of } \\
\text { learners. }\end{array}$ \\
\hline & $\begin{array}{l}\text { Examples and } \\
\text { demonstration }\end{array}$ & 0.116 & $\begin{array}{l}\text { Examples and demonstrations were given according to the } \\
\text { course content, to help learners make out the course } \\
\text { content. }\end{array}$ \\
\hline & $\begin{array}{l}\text { Communication and } \\
\text { collaboration }\end{array}$ & 0.095 & $\begin{array}{l}\text { Problems that required learners to communicate and } \\
\text { collaborate with each other were designed according to the } \\
\text { course content, and a communication platform was set up. }\end{array}$ \\
\hline & Exercise & 0067 & $\begin{array}{l}\text { Different levels of exercise were delivered to help learners } \\
\text { consolidate the knowledge and skills that they had learned. }\end{array}$ \\
\hline & Exercise feedback & 0.116 & $\begin{array}{l}\text { Learners can give and get effective feedbacks during } \\
\text { exercise }\end{array}$ \\
\hline & $\begin{array}{l}\text { Tests and } \\
\text { assessments }\end{array}$ & 0.089 & $\begin{array}{l}\text { Scientific and reasonable tests and assessments were } \\
\text { established to test the learning effect of learners. }\end{array}$ \\
\hline
\end{tabular}




\begin{tabular}{|c|c|c|c|}
\hline \multirow{4}{*}{$\begin{array}{l}\text { Interfacial } \\
\text { Design }(0.134)\end{array}$} & Screen layout & 0.192 & $\begin{array}{l}\text { The screen was concisely and beautifully designed, the } \\
\text { layout was well-proportioned and rational. }\end{array}$ \\
\hline & $\begin{array}{l}\text { Navigation and } \\
\text { orientation }\end{array}$ & 0.169 & $\begin{array}{l}\text { Learners can easily operate navigation paths and visit } \\
\text { various modules of the course without special help }\end{array}$ \\
\hline & $\begin{array}{l}\text { Operation } \\
\text { response }\end{array}$ & 0.565 & $\begin{array}{l}\text { Feedbacks were given to the learners' operations in the } \\
\text { forms of changes in visual effect or auditory cues, etc. }\end{array}$ \\
\hline & Operation help & 0.074 & $\begin{array}{l}\text { Detailed and complete instructions on operation and use } \\
\text { were offered }\end{array}$ \\
\hline \multirow{4}{*}{$\begin{array}{l}\text { Media } \\
\text { Technology } \\
(0.107)\end{array}$} & $\begin{array}{l}\text { Definition and } \\
\text { fluency of videos }\end{array}$ & 0.380 & $\begin{array}{l}\text { The video materials should have a high definition and } \\
\text { fluency. }\end{array}$ \\
\hline & $\begin{array}{l}\text { Layout of } \\
\text { texts and pictures } \\
\end{array}$ & 0.114 & $\begin{array}{l}\text { The text size was suitable, the pictures were clear and the } \\
\text { layout was aesthetic. }\end{array}$ \\
\hline & $\begin{array}{l}\text { Correctness and } \\
\text { clarity of subtitles }\end{array}$ & 0.074 & $\begin{array}{l}\text { The subtitles should match the course content, be correct } \\
\text { and clear. }\end{array}$ \\
\hline & \begin{tabular}{|l} 
Teacher's \\
sense of lens
\end{tabular} & 0.432 & $\begin{array}{l}\text { The teachers should behave naturally in front of the camera } \\
\text { and have eye contact with the camera. }\end{array}$ \\
\hline \multirow{3}{*}{$\begin{array}{l}\text { Course } \\
\text { Management } \\
(0.078)\end{array}$} & Policy support & 0.333 & $\begin{array}{l}\text { Appropriate financial, manpower and material supports } \\
\text { were provided for } \\
\text { course development, management rules were formulated } \\
\text { and the development process was standardized }\end{array}$ \\
\hline & $\begin{array}{l}\text { Team } \\
\text { management }\end{array}$ & 0.333 & $\begin{array}{l}\text { The qualifications of lecturers were examined, the } \\
\text { authenticity of application materials was checked, the } \\
\text { course was organized and developed in a group manner and } \\
\text { the functions of various organizational structures were } \\
\text { coordinated }\end{array}$ \\
\hline & $\begin{array}{l}\text { Development and } \\
\text { management of } \\
\text { course }\end{array}$ & 0.333 & $\begin{array}{l}\text { The overall plan of the course development was drawn up, } \\
\text { management rules were formulated, the development } \\
\text { process was standardized and the follow-up operation was } \\
\text { maintained. }\end{array}$ \\
\hline
\end{tabular}

From the data in the above table, it was not hard to see that the comprehensive evaluation indicator system should encompass 5 primary categories, course content, teaching design, interface design, media technology, and course management, and 25 secondary categories and form a systematic, institutionalized and scientific education mode. Such an education system can improve the teaching effect of the teaching platform, provide teaching thoughts and basis for educators in the application of hierarchical embedded service mode in the teaching of library information literacy, guide learners to learn efficiently and independently and offer a guarantee for the continuous improvement of education system. 


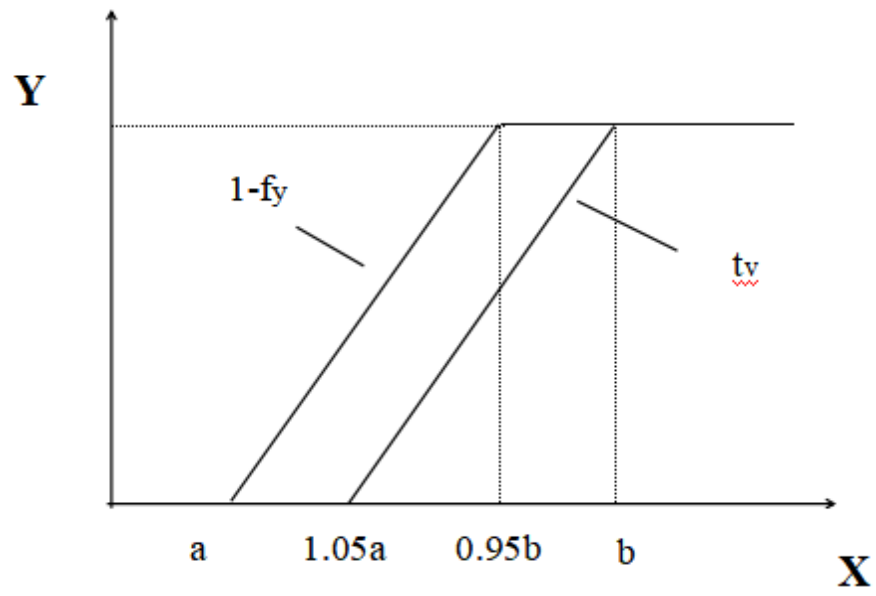

Fig. 4. Membership Function Diagram

Fig. 4 showed the structure of the vague set membership function, which was the ground of the establishment of comprehensive evaluation indicators. Suppose that any value the domain $\mathrm{X}$ was $\mathrm{x}$, and the $\mathrm{V}$ of vague set in $\mathrm{X}$ was represented by the function $\operatorname{tv} \cdot \operatorname{tv}(\mathrm{x})$ was the lower bound of the positive membership of $X$, while $\mathrm{fv}(\mathrm{x})$ was the lower bound of the negative membership of $\mathrm{x} . \mathrm{t}(\mathrm{x})$ and $\mathrm{fv}(\mathrm{x})$ connected a real number in the interval $[0,1]$ with every point in $\mathrm{x}$.

For example, a vague set $\mathrm{v}$ used a true membership $\operatorname{tv}(\mathrm{x})$ and a false membership $\mathrm{fv}(\mathrm{x})$ to describe the boundaries of their membership degrees. These two boundaries constituted the subinterval $[\operatorname{tv}(\mathrm{x}), 1-\mathrm{fv}(\mathrm{x})]$ on $[0,1]$, which symbolized "belonging to... within a certain scope". It was a mathematical model for objective things with pros, cons and neutrality.

Based on the above description, the author did calculation using the following conditions and formulas and concluded that:

Suppose it was a non-empty set, $\mathrm{V}$ was a set composed of all vague sets on $\mathrm{U}$, $\mathrm{A} \in \mathrm{U}, \mathrm{B} \in \mathrm{U}, \mathrm{M}: \mathrm{V} \times \mathrm{V}-\mathrm{f} 0,1]$. If $\mathrm{M}(\mathrm{A}, \mathrm{B})$ satisfied the following property:

1. $0 \leq \mathrm{M}(\mathrm{A}, \mathrm{B}) \leq 1$

2. If $A=B$, then $M(A, B)=1$

3. $\mathrm{M}(\mathrm{A}, \mathrm{B})=\mathrm{M}(\mathrm{B}, \mathrm{A})$

Then $\mathrm{M}(\mathrm{A}, \mathrm{B})$ was referred to as the similarity between $\mathrm{A}$ and $\mathrm{B}$. The calculation formula for similarity was as follows:

The similarity was calculated using the similarity measurement formula improved.

$$
M(x, y)=\frac{1-I s(x)-s(y) l}{8}-\frac{\left(L t_{x}-t_{y} L+L f_{x}-f_{y} l\right)}{8}-\frac{\left(I t_{x}-t_{y}+f_{x}-f_{y} l\right)}{4}
$$


Supposed that A and B were two vague sets, then the similarity between A and B can be calculated by the function $T, T \in[0,1]$. The greater value it had, the higher similarity between vague sets $\mathrm{A}$ and $\mathrm{B}$, where:

$$
\mathrm{T}(\mathrm{A}, \mathrm{B})=\sum_{i=1}^{n} W_{i} * M\left(V_{A}\left(X_{i}\right), V_{B}\left(X_{i}\right)\right)
$$

Where the higher similarity, the better evaluation the course received.

\section{$4 \quad$ Teaching Example and Effect}

\subsection{Teaching example}

The learning process and teaching process of hierarchical embedded service mode started from the teaching management of liberal education course. The leaning effect of liberal education course in which information literacy was embedded was obtained through scientific teaching methods, diversified teaching activities, well-established teaching means and efficient evaluation methods. Teachers, librarians and students were participants of this teaching mode. The specific teaching process is shown in Fig. 5. Fig. 6 shows the learning process of hierarchical embedded service mode and the interaction between teachers and students during the teaching.

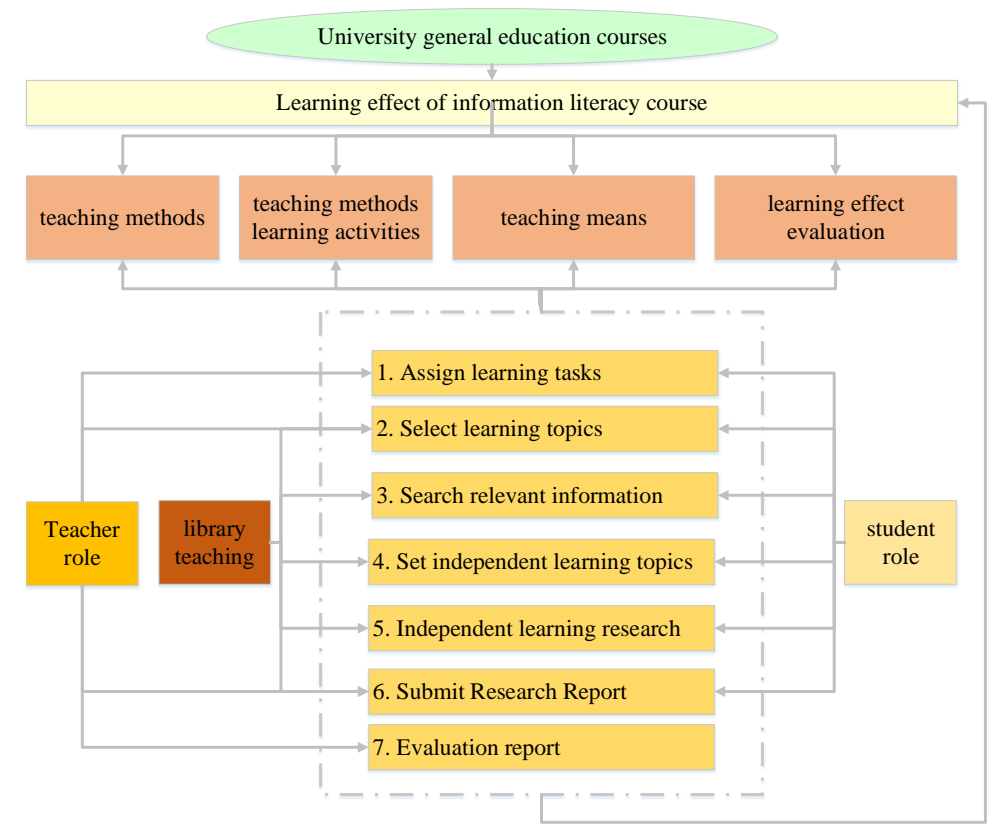

Fig. 5. The Learning Process and Teaching Process of Hierarchical Embedded Service Mode 


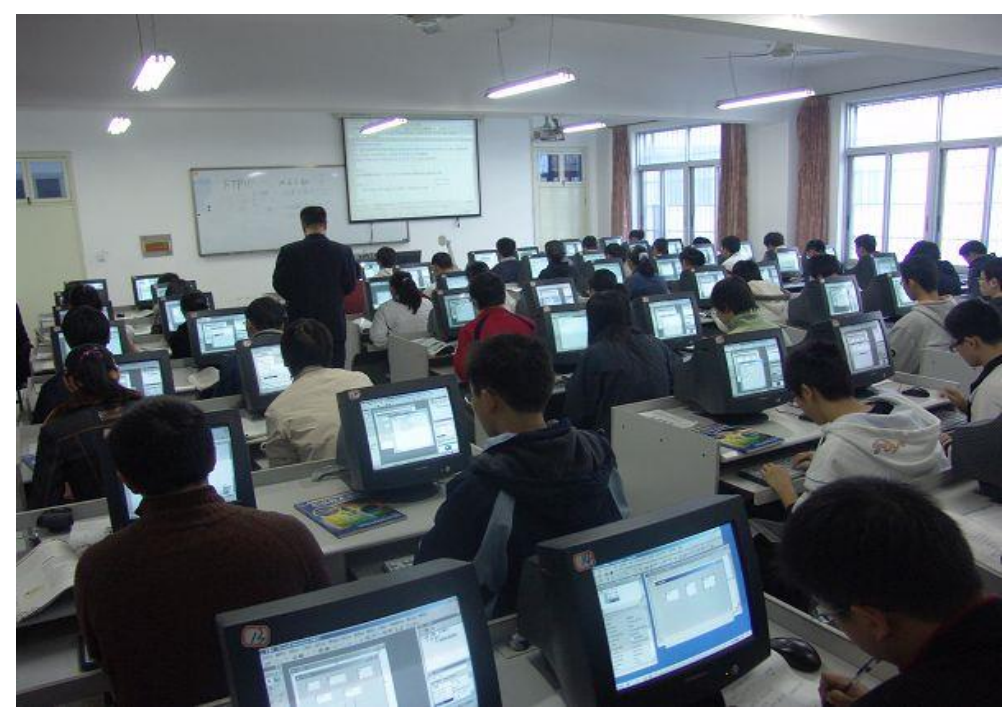

Fig. 6. Interaction between Teachers and Students in Library Information Literacy Course http://blog.sina.com.cn/s/blog_70e6bae10101hjsa.html

In this study, three classes were selected randomly from the website of library information literacy course of a given university: freshmen from the School of Cultural Communication, the School of Arts, and the School of Business Administration, the class names were replaced by Class 1, Class 2, and Class 3 respectively. 50 students were asked to learn courses of these three classes, and evaluated various indicators of these courses. A vague set was established for "very good" evaluation in three classes, and a vague set was established for ideal indexes. The results in Tab.3 were calculated using the following formula:

$$
\mathrm{T}(\mathrm{A}, \mathrm{B})=\sum_{i=1}^{n} W_{i} * M\left(V_{A}\left(X_{i}\right), V_{B}\left(X_{i}\right)\right)
$$

Table 3. Merits and Demerits of the Library Information Literacy Course Based on Vague Sets

\begin{tabular}{|c|c|c|c|c|c|c|c|c|c|c|c|}
\hline \multirow[b]{2}{*}{$\begin{array}{c}\text { Primary } \\
\text { Index }\end{array}$} & \multirow[b]{2}{*}{ Secondary Index } & \multicolumn{4}{|c|}{ Vague Set (Course) } & \multicolumn{3}{|c|}{ Course Similarity } & \multicolumn{3}{|c|}{$\begin{array}{c}\text { Module } \\
\text { Similarity }\end{array}$} \\
\hline & & $C I$ & C II & C III & $\begin{array}{l}\text { Ideal } \\
\text { Index }\end{array}$ & $C I$ & C II & C III & $C I$ & C II & C III \\
\hline \multirow{5}{*}{$\begin{array}{l}\text { Course } \\
\text { Content }\end{array}$} & \begin{tabular}{|l|}
$\begin{array}{l}\text { Course } \\
\text { introduction }\end{array}$ \\
\end{tabular} & $\begin{array}{c}{[0.915,} \\
0.975] \\
\end{array}$ & $\begin{array}{l}\text { [0.925, } \\
0.975]\end{array}$ & $\begin{array}{c}{[0.65,} \\
0.65]\end{array}$ & {$[1,1]$} & 0.963 & 0.9 & 0.838 & \multirow{5}{*}{0.981} & \multirow{5}{*}{0.918} & \multirow{5}{*}{0.845} \\
\hline & $\begin{array}{l}\text { Consistency } \\
\text { between content } \\
\text { and objective }\end{array}$ & $\begin{array}{c}{[1,} \\
0.945]\end{array}$ & $\begin{array}{l}{[0.9,} \\
0.95]\end{array}$ & $\begin{array}{l}{[0.675,} \\
0.675]\end{array}$ & {$[1,1]$} & 0.975 & 0.913 & 0.813 & & & \\
\hline & Scientificity & $\begin{array}{l}0.905, \\
0.945]\end{array}$ & $\begin{array}{l}{[0.875,} \\
0.875]\end{array}$ & $\begin{array}{c}{[0.65,} \\
0.8]\end{array}$ & {$[1,1]$} & 0.95 & 0.925 & 0.825 & & & \\
\hline & $\begin{array}{l}\text { Knowledge } \\
\text { quantity }\end{array}$ & $\begin{array}{c}0.875, \\
0.975]\end{array}$ & $\begin{array}{l}{[0.925,} \\
0.975]\end{array}$ & $\begin{array}{c}0.875, \\
0.875]\end{array}$ & {$[1,1]$} & 0.938 & 0.913 & 0.838 & & & \\
\hline & Content & {$[0.925$,} & {$[0.8,0$. } & {$[0.675$,} & {$[1,1]$} & 0.963 & 0.913 & 0.8 & & & \\
\hline
\end{tabular}




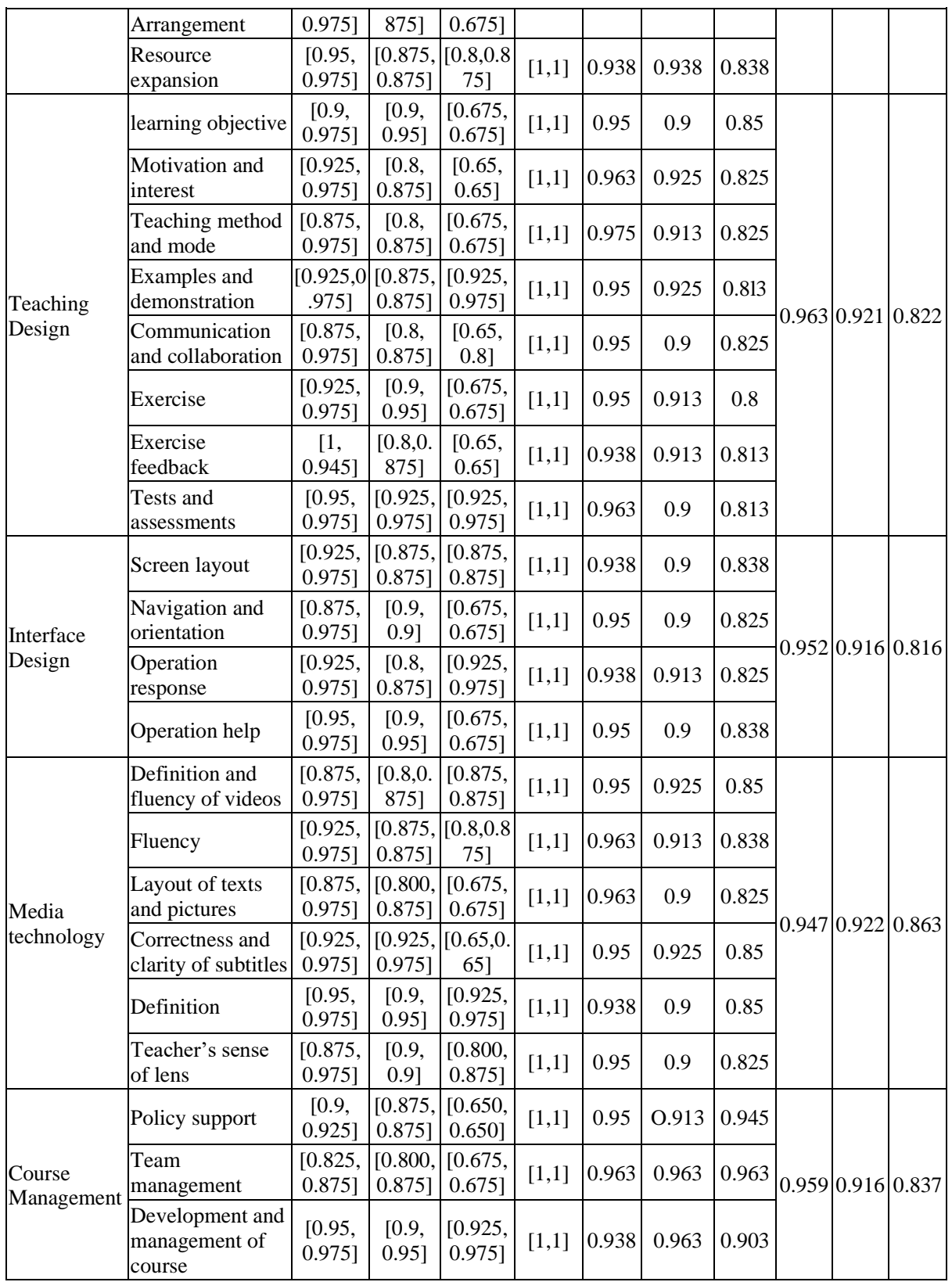

From the calculation results in Tab. 4, it can be found that there was high similarity between the data of each course, the course evaluation was excellent, among which the evaluations of Course I and Course II were better than that of Course III. 


\subsection{Teaching effect}

From the results in Tab. 4, it can be seen that the excellent and good rates of students who were trained by hierarchical embedded service mode in library information literacy course were $86 \%$, which was far higher than those of students who were not trained.

Table 4. Comparison of Students' Scores in the Final Theory Exam

\begin{tabular}{|l|c|c|c|c|c|}
\hline \multicolumn{1}{|c|}{ Group } & Excellent & Good & Average & Poor & Excellent and Good Rates (\%) \\
\hline Experimental Group $(\mathrm{n}=50)$ & 28 & 15 & 7 & 0 & 86 \\
\hline Control Group $(\mathrm{n}=50)$ & 21 & 12 & 14 & 3 & 66 \\
\hline
\end{tabular}

Table 5. Students' Evaluation of the Teaching Mode

\begin{tabular}{|l|c|c|c|c|}
\hline \multicolumn{1}{|c|}{ Group } & $\begin{array}{c}\text { Students' } \\
\text { Autonomous } \\
\text { Ability }\end{array}$ & $\begin{array}{c}\text { The Learning } \\
\text { Interest was } \\
\text { Stimulated }\end{array}$ & $\begin{array}{c}\text { The Classroom } \\
\text { Activity was } \\
\text { Enhanced }\end{array}$ & $\begin{array}{c}\text { The Reading } \\
\text { Ability was } \\
\text { Improved }\end{array}$ \\
\hline Experimental Group (n=50) & 48 & 48 & 47 & 48 \\
\hline Control Group (n=50) & 39 & 41 & 43 & 44 \\
\hline
\end{tabular}

From the evaluation results in Tab. 6, it can be seen that through the cultivation of this teaching mode, students had been greatly improved in terms of autonomous learning ability, learning interest, classroom activity and reading ability.

\section{Conclusion}

Hierarchical embedded service mode is an advanced teaching mode in the teaching of library information literacy course, but seldom practiced in China. The teaching effect of this teaching mode is verified through vague sets, and the following conclusions are drawn:

1. Hierarchical embedded service mode is a systematic teaching mode in the teaching of library information literacy course, which requires the joint participation of teachers, librarians and students. It transforms the traditional teaching mode and turns over a new leaf in teaching. It is an effective teaching method that can improve students' autonomous learning ability, learning interest, classroom activity, reading ability and academic records;

2. The application of hierarchical embedded service mode in the teaching of library information literacy course can help learners improve their innovative and entrepreneurial abilities and offer a guarantee for the society to train talents that can facilitate the overall development of China;

3. The evaluation system for the application of hierarchical embedded service mode in the teaching of library information literacy course is very crucial and on-going validation is required to optimize teaching strategies and improve the teaching effect. 
4. During the research of this paper, 50 freshmen from the School of Cultural Communication, the School of Arts, and the School of Business Administration were selected, so the research is one-sided to a certain degree. Currently, there are relatively few practical studies on this teaching mode in China, so they need to be launched and verified continuously.

\section{$6 \quad$ References}

[1] Tatnall, A., Kereteletswe, O.C., \& Visscher, A. Information technology and managing quality education. Information technology and managing quality education, 2017, vol. 348(3), pp. 3-4. https://doi.org/10.1007/978-3-642-19715-4

[2] Mathiesen, K. Informational justice: a conceptual framework for social justice in library and information services. Library Trends, 2017, vol. 64(2), pp. 198-225. https://doi.org/10. 1353/lib.2015.0044

[3] Xia, D., Li, J., Zhou, L. Design of Visual Education Resource Library Based on 3D Modeling. International Journal of Emerging Technologies in Learning, 2018, vol. 13(11), pp. 170-183. https://doi.org/10.3991/ijet.v13i11.9609

[4] Vossler, J.J., \& Watts, J. Educational story as a tool for addressing the Framework for information literacy for higher education. portal: Libraries and the Academy, 2017, vol. 17(3), pp. 529-542. https://doi.org/10.1353/pla.2017.0033

[5] Conor, E. Engaging students in disciplinary practices: music information literacy and the acrl framework for information literacy in higher education. Notes, 2016, vol. 73(1), pp. 921. https://doi.org/10.1353/not.2016.0087

[6] Woodward, K.M. Students at the Center in emerging academic models: embedded information literacy and distance services in the University of Wisconsin System Flex Degree. Library Hi Tech News, 2015, vol. 32(7), pp. 12-15. https://doi.org/10.1108/lhtn04-2015-0023

[7] Lamb, A. Debunking the librarian 'gene': designing online information literacy instruction for incoming library science students. Journal of Education for Library and Information Science, 2017, vol. 58(1), pp. 15-26. https://doi.org/10.3138/jelis.58.1.15

[8] Moto, S., Ratanaolarn, T., Tuntiwongwanich, S., \& Pimdee, P. A Thai junior high school students' 21 st century information literacy, media literacy, and ICT literacy skills factor analysis. International Journal of Emerging Technologies in Learning, 2018, vol. 13(9), pp. 87-106. https://doi.org/10.3991/ijet.v13i09.8355

[9] Yang, Z.H. Design of modular online information literacy curriculum for medical students. Chinese Journal of Medical Education, 2018, vol. 38(5), pp. 672-675.

[10] Li, S.J., Yi, Y.T., Chen, L.J., Zhang, P., Cui, G.H. Analysis on the level of electronic health literacy of college students in Jinan and its influencing factors. Chinese Journal of School Health, 2019, vol. 40(7), pp. 1071-1074

[11] Chen, L., He, H.Z., Gao, F. Research on the Hierarchical Embedded Information Literacy Education Model in the new form. Journal of Library and Information Sciences in Agriculture, 2017, vol. 29(5), pp. 151-153.

[12] Bell, S., Lewis, J.P. A survey of civic engagement education in introductory canadian politics courses. Journal for the Scholarship of Teaching and Learning, 2015, vol. 6(1), pp. 1-21. https://doi.org/10.5206/cjsotl-rcacea.2015.1.2 
Paper-Teaching Mode of Library Information Literacy Course Based on Hierarchical Embedded Service

\section{Author}

Lu Pang is a librarian in the Shandong Women's University, Jinan, China (pangxiaolu123456@163.com).

Article submitted 2020-01-29. Resubmitted 2020-03-06. Final acceptance 2020-03-09. Final version published as submitted by the authors. 